\title{
KEMAMPUAN DAN HASIL BELAJAR TIK MATERI MICROSOFT EXCEL MELALUI PROYEKTOR LCD SISWA KELAS VIII.D SMP
}

\author{
Murni \\ SMP Negeri 1 Teras Boyolali \\ Murnitomo60@gmail.com
}

\begin{abstract}
The purpose of research, to improve the ability and learning outcomes of Information Technology and Communication materials Microsoft Excel via LCD Projector learners VIII D Junior High School 1 Teras Boyolali second semester of 2015/2016. This type of research is a classroom action research. The subject of research students in grade VIII D amounted to 31 students. Data were collected through observation and tests. Data analysis techniques with methods pestle and kamparasi. The results of the research, and the ability of the acquisition value of the Information and Communication Technology learning materials Microsoft Excel learners VIII D 2015/2016 Semester even-numbered years, always increase from one cycle to the next cycle. It indicates an increased ability and learning outcomes of students in the material Microsoft Excel. In accordance whole cycle has been done. Implementation of learning using an LCD projector media may actually enhance the ability and learning outcomes of students. In each cycle always bring a positive impact towards improving the ability and learning outcomes of students. Besides the application of learning with LCD projectors create a classroom atmosphere becomes conducive, students become interested, active, creative, effective and fun and no saturation.
\end{abstract}

Keywords: ability, learning outcomes, ICT, LCD

\begin{abstract}
ABSTRAK
Tujuan penelitian, untuk meningkatkan kemampuan dan hasil belajar Tehnologi Informasi dan Komunikasi materi Microsoft Excel melalui Proyektor LCD pada peserta didik kelas VIII D Sekolah Menengah Pertama Negeri 1 Teras Boyolali semester genap tahun 2015/2016. Jenis penelitian ini penelitian tindakan kelas. Subjek penelitian peserta didik kelas VIII D berjumlah 31 siswa. Data dikumpulkan melalui observasi dan tes. Teknik analisis data dengan metode alu dan kamparasi. Hasil penelitian, kemampuan dan perolehan nilai dalam pembelajaran Tehnologi Informasi dan Komunikasi materi Microsoft Excel peserta didik kelas VIII D Semester genap tahun 2015/2016, selalu mengalami peningkatan dari satu siklus ke siklus berikutnya. Hal itu mengindikasikan adanya peningkatan kemampuan dan hasil belajar peserta didik pada materi Microsoft Excel. Sesuai keseluruhan siklus yang telah dilakukan. Penerapan pembelajaran menggunakan media proyektor LCD ternyata dapat meningkatkan kemampuan dan hasil belajar peserta didik. Dalam setiap siklus selalu membawa dampak yang positif kearah peningkatan kemampuan
\end{abstract}


dan hasil belajar peserta didik. Selain itu penerapan pembelajaran dengan proyektor LCD membuat suasana kelas menjadi kondusif, peserta didik menjadi tertarik, aktif, kreatif, efektif dan menyenangkan serta tidak ada kejenuhan.

Kata kunci: kemampuan, hasil belajar, TIK, LCD

\section{PENDAHULUAN}

Sekolah merupakan bagian dari sistem pendidikan formal yang mempunyai aturan-aturan jelas atau lebih dikenal dengan Silabus Pembelajaran sebagai acuan proses pembelajaran dan guru sebagai fasilitator yang berperan dalam keberhasilan seorang peserta didik, sehingga guru harus tepat dalam memilih model, metode, dan media pembelajaran yang akan digunakan. Microsoft Excel adalah salah satu materi pelajaran Teknologi Informasi dan Komunikasi ( TIK ) untuk kelas VIII pada semester II sebagai salah satu kompetensi dasar yang terdapat dalam silabus pembelajaran. Pada setiap pembelajaran di ruang komputer materi disampaikan dengan cara peserta didik masuk ke dalam laboratorium komputer secara bersama sama atau kelasikal, hal ini dilakukan agar supaya peserta didik dapat mempraktekkan komputer secara langsung dan peserta didik dapat mendengarkan penjelasan peneliti kemudian melakukan apa instruktuksi dari peneliti tersebut. Jumlah seluruhpeserta didik yang berjumlah 31 terdiri dari jumlah peserta didik putri 15 dan peserta didik putra 16. Jumlah komputer yang ada sebanyak 20 unit dan itupun terkadang sering terjadi kemacetan saat sedang digunakan. Karena alasan tertentu diantaranya banyak komputer yang tidak bisa dioperasikan sehingga membuatpeserta didik menggunakan satu unit komputer digunakan dua orang.

Kondisi pembelajaran yang selama ini digunakan yaitu menggunakan metode ceramah, tanya jawab dan demontrasi (praktek komputer secara langsung). Peneliti menjelaskan materi yang akan dipraktekkan, peserta didik mendengarkan sambil mencatat penjelasan peneliti terkadang masih ada juga peserta didik yang berbicara sendiri dan tidak mau mencatat apa yang telah dijelaskan oleh peneliti. Kemudian peneliti memberikan beberapa pertanyaan tentang materi yang telah disampaikan yaitu tentang mengidentifikasi materi program Microsoft Excel kepada peserta didik. Peserta didik yang menjawab pertanyaan peneliti hanya beberapa peserta didik saja, sedangkan yang lainnya ada yang belum mengerti materi tersebut. Pada saat peneliti mengajukan pertanyaan tentang apakah peserta didik sudah jelas dengan materi ini, peserta didik hanya diam saja dan belum bersemangat untuk menjawab pertanyaan. Menurut peneliti kondisi ini disebabkan karena peserta didik baru saja menjalani libur semester I dengan waktu 2 minggu, kemungkinan peserta didik selama liburan dirumah tidak pernah belajar sehingga pada saat peserta didik masuk pertama, peserta didik masih belum bersemangat untuk belajar kembali di sekolah. Dan mengakibatkan pembelajaran di awal semester II belum berjalan dengan baik sesuai dengan rencana peneliti. Untuk mengetahui hasil belajar peserta didik penulis memberikan beberapa lembar kerja peserta didik berupa soal-soal agar dikerjakan di rumah, kemudian pada pertemuan berikutnya dibahas bersama-sama. Selain dengan memberikan pekerjaan rumah kepada peserta didik, peneliti juga menyuruh peserta didik maju ke depan papan tulis untuk menjawab pertanyaan yang diajukan oleh peneliti. 
Kondisi pembelajaran seperti itu maka menimbulkan beberapa permasalahan diantaranya peneliti masih menggunakan metode ceramah, tanya jawab dan demontrasi masih membuat peserta didik belum memahami materi Microsoft Excel secara maksimal. Apabila secara teoritis materi ini diberikan ke peserta didik, peserta didikkadang-kadang sudah bisa memahami apa fungsi atau kegunaan dari program Microsoft Excel, akan tetapi apabila diterapkan secara praktek, banyak peserta didik yang belum bisa mempraktekkan hal ini disebabkan karena banyak peserta didik yang tidak mempunyai komputer/laptop/notebook di rumah, sehingga peserta didik tidak dapat belajar praktek komputer di rumah. Peserta didik hanya belajar praktek di sekolah dengan waktu yang sangat terbatas yaitu satu minggu hanya satu kali pertemuan dengan waktu 2 jam pelajaran, hasil belajar pada setiap pengerjaan latihan tidak tercapai tepat waktu, penyampaian materi dengan menggunakan LCD Proyektor cukup membantu guru dalam menjelaskan materi tetapi itu juga belum maksimal, menyampaikan materi ke peserta didik jarang mendapatkan pelajaran teori sehingga sering lupa materi pelajaran (teori, perintah, gambar dan cara-cara melakukan), hasil pembelajaran sangat kurang memuaskan karena banyak peserta didik yang tidak dapat mengerjakan soal-soal latihan dengan benar.

Atas dasar kenyataan inilah, maka perlu dicari alternatif lainnya dengan melakukan inovasi dan pendekatan, baik itu dalam penggunaan media ataupun metode penyampaian sehingga proses pembelajaran dapat berlangsung aktif, efektif dan menyenangkan.Karena media pembelajaran merupakan salah satu alat untuk mempertinggi proses interaksi guru dengan peserta didikdan interaksi peserta didik dengan lingkungan dan sebagai alat bantu mengajar dapat menunjang penggunaan metode mengajar yang digunakan oleh guru dalam proses belajar mengajar. Oleh karena itu, maka peneliti mencoba akan menerapkan Penggunaan Proyektor LDC untuk Meningkatkan Kemampuan dan Hasil Belajar TIK Materi Microsoft Excel Peserta didikKelas VIII D Semester II SMP N 1 TerasBoyolali dalam mempraktekkan latihan kerja peserta didik. Dalam sudut pandang proses pembelajaran, presentasi merupakan salah satu metode pembelajaran. Penggunaannya yang menempati frekwensi paling tinggi dibandingkan dengan metode yang lainnya. Berbagai alat yang dikembangkan, telah memberikan pengaruh yang sangat besar bukan hanya pada pengembagan kegiatan praktis dalam kegiatan presentasi pembelajaran akan tetapi juga pada teori-teori yang mendasarinya. Dengan harapan adanya penggunaan model, pendekatan-pendekatan dan metode serta media pembelajaran yang inovatif agar kegiatan pembelajaran peserta didikmampu mewujudkan pembelajaran yang kondusif, aktif, kreatif, efektif dan menyenangkan.

Kemampuan adalah kesanggupan atau kecakapan seorang individu dalam menguasai suatu keahlian dan digunakan untuk mengerjakan beragam tugas dalam suatu pekerjaan. Menurut Stephen P. Robbins \& Timonthy A. Judge (2009: 57-61) menyatakan bahwa kemampuan keseluruhan seorang individu pada dasarnya terdiri atas dua kelompok faktor, yaitu : a. Kemampuan Intelektual (Intelectual Ability), merupakan kemampuan yang dibutuhkan untuk melakukan berbagai aktifitas mental ( berfikir, menalar dan memecahkan masalah), b. Kemampuan Fisik (Physical Ability), merupakan kemampuan melakukan tugas-tugas yang menuntut stamina, ketrampilan, kekuatan, dan karakteristik serupa.

Soedijarto (1993:49) mengatakan bahwa hasil belajar adalah sebagai tingkat penguasaan yang dicapai oleh peserta didik dalam mengikuti proses belajar mengajar sesuai dengan tujuan pendidikan yang ditetapkan. Pengertian lain menjelaskan bahwa hasil belajar adalah 
kemampuan yang dimiliki peserta didik setelah ia ingin menerima pengalaman belajar atau yang optimal yang dapat dicapai dari kegiatan belajar di sekolah untuk pelajaran.

Microsoft Excel adalah program aplikasi spreed sheet yang didesain untuk keperluan bisnis dan perkantoran yang populer dan paling banyak digunakan saat ini. Dengan Microsoft Excel, pembuatan lembar kerja berupa tabel dengan perhitungan angka yang rumit dapat dikerjakan dengan mudah (Putra, 2009:2). Microsoft Excel dapat juga digunakan untuk menyelesaikan berbagai keperluan administrasi, dari yang sederhana sampai dengan yang rumit. Pada pemakaian keperluan yang sederhana tersebut misalkan untuk membuat perencanaan kebutuhan suatu perusahaan, berupa perencanaan barang kebutuhan, jumlah maupun harganya.

Pada Microsoft Excel bekerjanya dengan sistem workbook, sedangkan di dalam workbook terdapat worksheet atau lembar kerja. Pada worksheet ini kita bekerja dengan menggunakan kolom dan baris yang membentuk kotakan kecil-kecil berupa sel-sel tempat kita memasukkan data.

Proyektor LCD menurut Hamzah dan Lamatenggono (2010:131) mengemukakan bahwa media yang diproyeksikan ke layar dengan menggunakan alat khusus yang dinamakan proyektor (overhead projector, slide projector, slide projector, opaque projector). Dengan perkembangan tehnologi telah memungkinkan komputer dan video dapat diproyeksikan dengan menggunakan peralatan khusus yaitu LCD. Menurut Dwi Jo pengertian (2011:11) LCD proyektor adalah perangkat yang dapat menampilkan gambar dalam ukuran besar dan biasanya digunakan sebagai alat bantu dalam presentasi.

Penggunaan Multimedia Presentasi digunakan untuk menjelaskan materi-materi yang bersifat teoritis, digunakan dalam pembelajaran klasikal dengan group belajar yang cukup banyak. Media ini cukup efektif sebab menggunakan multimedia proyektor yang memiliki jangkauan pancar yang cukup besar (Rusman,2012:147). Kelebihan media ini adalah menggabungkan semua unsur media seperti teks, video, animasi, image,grafik dan sound menjadi satu kesatuan penyajian sehingga mengakomodasi sesuai dengan modalitas belajar siswa. Penggunaan media dengan memanfaatkan proyektor LCD dapat menjangkau banyak orang. Pembelajaran dengan penggunaan presentasi PowerPoint antara lain dapat membantu siswa dalam memahami dan menguasai bahan pembelajaran dengan lebih efektif.

Salah satu pendekatan pembelajaran yang diduga mampu mewujudkan situasi pembelajaran yang kondusif, aktif, kreatif, efektif, dan menyenangkan serta menarik adalah pendekatan dengan metode presentasi audio/visual. Menurut Sudjana (1989:30) yang termasuk dalam komponen pembelajaran adalah "tujuan, bahan, metode dan alat serta penilaian“. Melalui media pembelajaran Proyektor dengan Program Presentasi Power Point, akan membangkitkan motivasi siswa dan lebih mudah menerima dan memahami materi pokok pembelajaran Teknologi Informasi dan Komunikasi. Teknologi yang memanfaatkan LCD Proyektor sebagai perangkat utama untuk mengolah data menjadi informasi yang bermanfaat.

Seiring perkembangan zaman, Informasi Dan Teknologi (IT) LCD Proyektor memiliki fungsi yang sangat besar dan penting dalam kehidupan sehari-hari, baik dibidang pendidikan maupun bidang-bidang lainnya.Keuntungan pembelajaran menggunakan media Informasi Dan Teknologi (IT) LCD Proyektor antara lain :a) Menimbulkan motivasi dalam menekuni 
materi yang disajikan.b) Kemampuan untuk mengingat secara cepat dan tepat dalam merencanakan langkah selanjutnya.c) Dengan adanya warna, musik dan grafik yang dianimasi dapat merangsang untuk latihan, kegunaan laboraturium dan simulasi.d) Kecepatan dalam menanggapi respon peserta didik atau siswa.e) Kemampuan untuk menyimpan dokumen secara aman.

Penelitian dilakukan dengan tujuan umum untuk meningkatkan kemampuan dan hasil belajar TIK Materi Microsoft Excel peserta didikkelasVIII D diSMP N 1 TerasBoyolali Semester II Tahun Pelajaran 2015/2016 dan mengetahui efektifitas Pemanfaatan Proyektor LCD di Laboratorium Komputer dalam membimbing peserta didikkelas VIII DSMP N 1 Teras Boyolali Semester II pada mata pelajaran Teknologi Informasi \& Komunikasi (TIK) materi Microsoft Excel. Dalam penelitian ini peneliti mempunyai tujuan khusus, yaitu untuk meningkatkan kemampuan dan hasil belajar TIK Materi Microsoft Excel melalui Proyektor LCD peserta didikkelasVIII DSMP N 1 TerasBoyolali Semester II Tahun Pelajaran 2015/2016.

\section{METODE}

Penelitian dilaksanakanmulai bulan Februari sampai dengan bulan Juni 2015 semester II Tahun Pelajaran 2015/2016. Bulan Februari minggu pertama digunakan peneliti untuk pengajuan usulan proposal dan pengajuan instrumen penelitian serta pengajuan ijin penelitian ke pihak sekolah SMP N 1 Teras Boyolali. Pada Minggu kedua di bulan Februari peneliti mengadakan pengumpulan datayang digunakan untuk bahan dalam proses pembuatan penelitian tindakan kelas ini, pengamatanatau observasi yang dilakukan peneliti yaitu yang berkaitan dengan jumlah peserta didik, perbandingan jumlah peserta didik antara laki-laki dan perempuan, kondisi awal peserta didikkelas VIII D, dimana semua data-data tersebut nantinya digunakan untuk Pengembangan Landasan Teoritis. Sedangkan untuk melaksanakan kegiatan persiapan untuk Kondisi Awal bagi peserta didik klas VIII Ddilakukan selain mengadakan kegiatan observasi peneliti mengadakan persiapan membuat materi ulangan mata pelajaran TIK (Teknologi Informasi dan Komunikasi )dengan materi Penggunaan Perangkat Lunak Pengolah Angka untuk Menyajikan Informasi dengan menggunakan Program Microsoft Excel secara tertulis.

Setelah peneliti membuat persiapan soal ulangan maka tahap berikutnya adalah mengadakan penyusunan instrumen yang dilaksnakan pada minggu ketiga bulan Februari. Pengambilan data dan Kondisi Awal dilaksanakan pada bulan Februari minggu ke empat dan kelima. Pada bulan Maret minggu pertama sampai minggu keduamasih dilakukan pengambilan data dan melakukan Tindakan untuk Siklus I. Minggu pertama bulan April mengadakan pengambilan data dan Tindakan untuk Siklus II dengan mengajak teman sejawat untuk mendiskusikan hasil pengamatan yang telah dilakukan. Analisis data dan pembahasan dilakukan pada minggu pertama bulan April sampai bulan April minggu ketiga. Sedangkan penyusunan laporan hasil penelitian mulai dilaksanakan pada minggu ketiga bulan April dan berakhir sampai dengan bulan Juni2015. Pengambilan data dilakukan pada bulan Februari hingga bulan April dikarenakan pada waktu tersebut karena materi yang sedang dipelajari adalah materi TIK (Teknologi Informasi dan Komunikasi) yaitu tentang Penggunaan perangkat Lunak Pengolah Angkauntuk Menyajikan Informasiyaitu menggunakanProgram 
Microsoft Excel yang diajarkan pada peserta didik kelas VIII D pada semester II Tahun Pelajaran 2015/2016.

Penelitian dilaksanakan di SMP N 1 Teras Boyolali dalam pembelajaran TIK (Tehnologi Informasi dan Komunikasi) materi Microsoft Excel peserta didik kelas VIII DSemester II Tahun Pelajaran 2015/2016. Alasan penelitian dilaksanakan di sekolah tersebut karena peneliti merupakan guru yang memiliki jam mengajar TIK (Tehnologi Informasi dan Komunikasi) kelas VIII D di sekolah tersebut. Di samping itu, kemampuan dan hasil belajar TIK materi Microsoft Excel di klas VIII D tersebut masih rendah.

Mengingat dalam penelitian tindakan kelas ini peneliti adalah Guru, maka subjeknya adalah peserta didik yakni peserta didik kelas VIII DSMP N 1 Teras Boyolali Semester II Tahun Pelajaran 2015/2016 yang terdiri atas 31peserta didik. Dengan jumlah peserta didik putri sebanyak 15 orang dan putra sebanyak 16 orang. Latar belakang pekerjaan orang tua peserta didik kelas VIII DSMP N 1 Teras Boyolali yaitu buruh sebanyak 14 orang, swasta sebanyak 14 orang dan petanisebanyak 3 orang. Sedangkan latar belakang pendidikan orang tua peserta didik yang tidak lulus SD sebanyak 2 orang, lulus SD sebanyak 14 orang, lulus SMP sebanyak 8 orang, lulus SMA sebanyak 6 orang dan yang lulus sarjana sebanyak 1 orang. Dengan melihat kondisi yang demikian itu sebagian besar peserta didik masih banyak yang kurang diperhatikan oleh orang tua mereka dikarenakan orang tua peserta didik masih bekerja seharian untuk mencukupi kebutuhan keluarga. Dilihat dari tingkat pendidikan orang tua yang rendah sehingga menyebabkan anak kurang dipantau dan didampingi dalam hal belajarnya dan mengakibatkan kemampuan belajar dan hasil belajar mereka rendah. Secara perekonomian, peserta didik klas VIII D dalam satu kelas yang mendapatkan Bantuan Peserta didik Miskin (BSM) sebanyak 6 anak dari 31peserta didik. Obyek penelitian yang dilakukan di kelas VIII DSMP N 1 Teras Boyolali adalah Peningkatan Kemampuan Belajar TIK materi Microsoft Excel, Peningkatan Hasil Belajar TIK materi Microsoft Excel, dan Media Proyektor LCD.

Sumber data dalam penelitian tindakan kelas ini berasal dari subyek penelitian atau dari peserta didik yang merupakan sumber data primer yaitu nilai ulangan harian peserta didik baik nilai ulangan harian sebelum tindakan kelas maupun setelah dilakukannya tindakan kelas oleh peneliti. Data-data tersebut terdiri dari 6 data yaitu : 1) Daftar Nilai Ulangan Harian Tertulis pada Kondisi Awal tentang peningkatkan Kemampuan Belajar TIK materi Microsoft Excel sebelum menggunakan proyektor LCD, 2) Daftar Nilai Ulangan Harian Praktek pada Kondisi Awal tentang peningkatkan Hasil Belajar TIK materi Microsoft Excel sebelum menggunakan proyektor LCD, 3) Daftar Nilai Ulangan Harian TertulisSiklus Itentang peningkatkan Kemampuan Belajar TIK materi Microsoft Excel sebelum menggunakan proyektor LCD, 4) Daftar Nilai Ulangan Harian Praktek Siklus I tentang peningkatkan Hasil Belajar TIK materi Microsoft Excel sebelum menggunakan proyektor LCD, 5) Daftar Nilai Ulangan Harian Tertulis Siklus II tentang peningkatkan Kemampuan Belajar TIK materi Microsoft Excel sesudah menggunakan proyektor LCD, dan 6) Daftar Nilai Ulangan Harian Praktek Siklus II tentang peningkatkan Hasil Belajar TIK materi Microsoft Excel sesudah menggunakan proyektor LCD.

Data Kondisi Awal penelitian untuk meningkatkan Kemampuan Belajar TIK materi Microsoft Excel peserta didik klas VIII D sebelum menggunakan proyektor LCD dikumpulkan 
menggunakan Teknik Dokumentasi, Instrumen/alat peraga berupa Dokumen, Catatan , Jurnal Pembelajaran dan Lembar Observasi. Data Kondisi Awal penelitian untuk meningkatkanHasil Belajar TIK materi Microsoft Excel sebelum menggunakan proyektor LCD dikumpulkan menggunakan Teknik Dokumentasi alatnya berupa Dokumen,Catatan danDaftar Nilai. Data Siklus I untuk meningkatkan Kemampuan Belajar TIK materi Microsoft Excel sebelum menggunakan proyektor LCD dikumpulkan menggunakan Tehnik Observasi dan alat tes berupa Lembar Observasi.

Data Siklus I untuk meningkatkan Hasil Belajar TIK materi Microsoft Excel sebelum menggunakan proyektor LCD dikumpulkan menggunakan Tes Tertullis dan Praktek, alat tesnya berupa Butir Soal Tertulis Siklus I. Data Siklus II untuk meningkatkan Kemampuan Belajar TIK materi Microsoft Excel sesudah menggunakan proyektor LCD dikumpulkan menggunakan Tehnik Observasi, alat tesnya berupa Lembar Observasi Siklus II. Data Siklus II untuk meningkatkan Hasil Belajar TIK materi Microsoft Excel sesudah menggunakan proyektor LCD dikumpulkan menggunakan Butir Soal Tes Tertulis dan Praktek, alat tesnya berupa Butir Soal Siklus II.

Dalam penelitian tindakan kelas ini yang dipergunakan adalah teknik pengumpulan data berbentuk tes. Pengertian tes adalah serentetan pertanyaan atau latihan atau alat lain yang digunakan untuk mengukur keterampilan, pengetahuan, intelegensi, kemampuan atau bakat yang dimiliki oleh individu atau kelompok (Suharsimi, 1996: 138). Sedangkan pengertian tes kemampuan (competence test) adalah tes yang diujikan untuk mengetahui kepemilikan kemampuan peserta tes. Yang termasuk ke dalam tes kemampuan adalah tes bakat,tes kecerdasan, tes kemampuan numerik, tes potensi akademik, tes penalaran, tes kemampuan berfikir kritis, dan sebagainya (Purwanto, 2011: 66).

Validitas adalah keadaan yang menggambarkan tingkat instrumen yang bersangkutan mampu mengukur apa yang akan diukur (SuharsimiArikunto, 2000 : 119). Validasi diperlukan agar diperoleh data yang valid. Adapun validitas yang digunakan perlu disesuaikan dengan data yang dikumpulkan. Untuk dapat kuantitatif (berbentuk angka) umumnya yang divalidasi instrumennya. Sedangkan data kualitatif (misalnya observasi, wawancara) dapat divalidasi melalui trianggulasi baik trianggulasi sumber maupun trianggulasi metode.

Mengingat data yang dihasilkan dalam penelitian ini berupa angka, maka validasi yang umumnya digunakan adalah validasi instrumen. Validitas yang digunakan meliputi validitas teoritik maupun validitas empirik. Instrumen dikatakan memiliki validitas yang baik jika instrumen tersebut secara analisis akan sudah sesuai dengan isi dan aspek yang diungkapkan. Jenis-jenis validitas terdiri atas : Validasi Data Peningkatan Kemampuan Belajar TIK materi Microsoft Excel Klas VIII DSMPN 1 Teras Semester II Tahun Pelajaran 2015/2016 pada Siklus I dan Siklus II diperoleh melalui Teknik Observasi dan alat tes berupa Lembar Observasi. Agar data menjadi lebih valid maka penulis melibatkan observer teman sejawat. Validasi Data Peningkatan Hasil Belajar TIK materi Microsoft Excel Klas VIII DSMP N 1 Teras Semester II Tahun Pelajaran 2015/2016 pada Siklus I dan Siklus II diperoleh menggunakan Teknik Tes Tertulis dan alat tes berupa Butir Soal Tes Tertulis dan dilengkapi dengan Kisikisi sebelum menyusun butir soal. Adapun jenis validasi data dalam penelitian tindakan kelas ini adalah validasi empirik yakni membandingkan butir-butir instrumen dengan kisi-kisinya yang telah disusun. 
Analisis Data Peningkatan Kemampuan Belajar TIK materi Microsoft Excel Klas VIII DSMP N 1 Teras Semester II Tahun Pelajaran 2015/2016 terdapat 3 data yaitu data Peningkatan Kemampuan Belajar TIK materi Microsoft Excel Kondisi Awal, data Peningkatan Kemampuan Belajar TIK materi Microsoft Excel Siklus I, dan data Peningkatan Kemampuan Belajar TIK materi Microsoft Excel Siklus II. Data tersebut dianalisis dengan menggunakan teknik Diskriptif Komparatif ( membandingkan ) kemudian dilanjutkan refleksi.

Diskriptif komparatif yaitu membandingkan secara diskripsi data Peningkatan Kemampuan Belajar TIK materi Microsoft Excel Klas VIII DSMP N 1 Teras Semester II Tahun Pelajaran 2015/2016Kondisi Awal dengan data Peningkatan Kemampuan Belajar TIK materi Microsoft Excel Klas VIII DSMP N 1 Teras Semester II Tahun Pelajaran 2015/2016 Siklus I, membandingkan data Peningkatan Kemampuan Belajar TIK materi Microsoft Excel Klas VIII DSMP N 1 Teras Semester II Tahun Pelajaran 2015/2016 Siklus I dengan data Peningkatan Kemampuan Belajar TIK materi Microsoft Excel Klas VIII DSMP N 1 Teras Semester II Tahun Pelajaran 2015/2016 Siklus II dan membandingkan data Peningkatan Kemampuan Belajar TIK materi Microsoft Excel Klas VIII DSMP N 1 Teras Semester II Tahun Pelajaran 2015/2016 Kondisi Awal dengan Kondisi Akhir. Refleksi yaitu membuat membuat simpulan berdasarkan Analisis Kritis dari hasil diskriptif Komparatif kemudian memberi ulasan guna menentukan perlu tidaknya tindakan siklus berikutnya.

Analisis Data Peningkatan Hasil Belajar TIK materi Microsoft Excel Klas VIII DSMP N 1 Teras Semester II Tahun Pelajaran 2015/2016 terdapat 3 data yaitu data Peningkatan Hasil Belajar TIK materi Microsoft Excel Kondisi Awal, data Peningkatan Hasil Belajar TIK materi Microsoft Excel Siklus I, dan data Peningkatan Hasil Belajar TIK materi Microsoft Excel Siklus II. Data tersebut dianalisis dengan menggunakan teknik Diskriptif Komparatif (membandingkan) kemudian dilanjutkan refleksi.

Setelah melakukan refleksi maka penulis membandingkan secara diskripsi, data Peningkatan Hasil Belajar TIK materi Microsoft Excel Klas VIII DSMP N 1 Teras Semester II Tahun Pelajaran 2015/2016 Kondisi Awal dengan data Peningkatan Hasil Belajar TIK materi Microsoft Excel Klas VIII DSMP N 1 Teras Semester II Tahun Pelajaran 2015/2016 Siklus I, membandingkan data Peningkatan Hasil Belajar TIK materi Microsoft Excel Klas VIII DSMP N 1 Teras Semester II Tahun Pelajaran 2015/2016 Siklus I dengan data Peningkatan Hasil Belajar TIK materi Microsoft Excel Klas VIII DSMP N 1 Teras Semester II Tahun Pelajaran 2015/2016 Siklus II dan membandingkan data Peningkatan Hasil Belajar TIK materi Microsoft Excel Klas VIII DSMP N 1 Teras Semester II Tahun Pelajaran 2015/2016 Kondisi Awal dengan Kondisi Akhir.

Dalam prosedur tindakan ini, langkah pertama peneliti menentukan metode yang digunakan dalam penelitian. Pada penelitian ini peneliti menggunakan metode Penelitian Tindakan Kelas. Langkah pertama, peneliti dalam penelitian ini tidak akan menggunakan metode kualitatif karena peneliti tidak akan mengeksplor permasalahan kemampuan dan hasil belajar peserta didik klas VIII D. Peneliti juga tidak menggunakan metode wawancara melainkan menggunakan metode Penelitian Tindakan Kelas ( PTK ). Peneliti menentukan tindakan-tindakan yang dilakukan dalam penelitian. Tindakannya yaitu menggunakan media Proyektor LCD. Langkah selanjutnya yaitu peneliti menentukan tahapan-tahapan Tindakan tiap Siklus. 
Pada Siklus I terdapat 4 tahapan terdiri dari : 1) Membuat Perencanaan Tindakan (planning), 2) Melakukan Tindakan sesuai yang dilaksanakan (acting), 3) Melakukan pengamatan terhadap Tindakan yang dilakukan ( observer ), dan 4) Melakukan Analisis Diskriptif Komparatif yang dilanjutkan dengan Refeksi terhadap Hasil Pengamatan Tindakan ( reflecting ).

Pada Siklus II terdapat 4 tahapan terdiri dari : 1) Membuat Perencanaan Tindakan (planning), 2) Melakukan Tindakan sesuai yang dilaksanakan ( acting ), 3) Melakukan pengamatan terhadap Tindakan yang dilakukan ( observer ), dan 4) Melakukan Analisis Diskriptif Komparatif yang dilanjutkan dengan Refeksi terhadap Hasil Pengamatan Tindakan ( reflecting ).

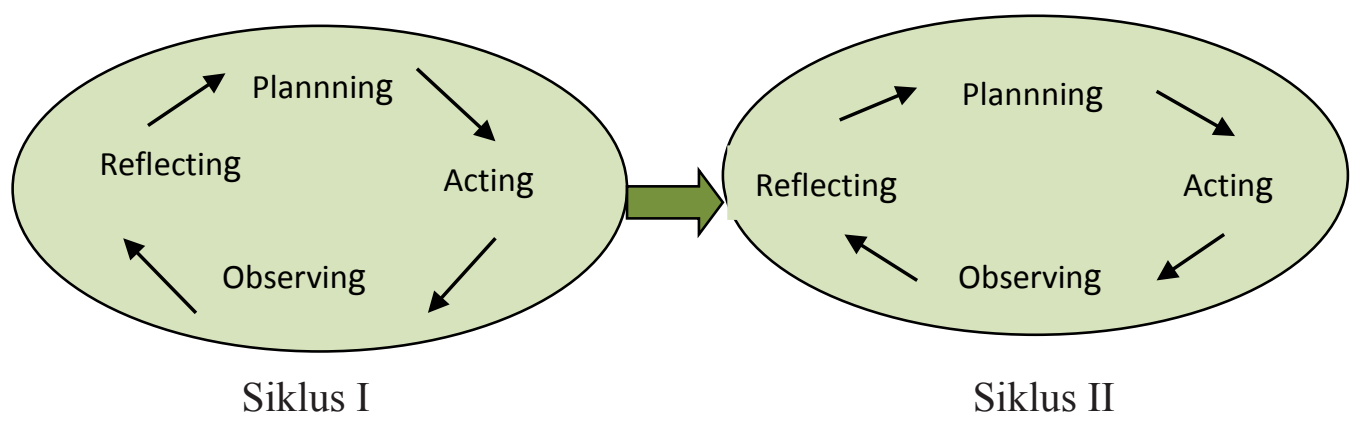

Gambar 1. Pelaksanaan Tindakan dalam 2 siklus

\section{HASIL DAN PEMBAHASAN}

Sebelum dilaksanakan kegiatan tindakan kelas berupa penggunaan media proyektor LCD dalam proses pembelajaran TIK, terlebih dahulu dilaksanakan kegiatan pre test untuk mengukur kemampuan dan hasil belajar peserta didik terhadap materi Microsoft Excel. Kegiatan pre test ini penting dilakukan sebagai dasar pertimbangan perlu tidaknya untuk melanjutkan tindakan kelas yang telah direncanakan.

Hasil pre test hasil belajar pada kondisi awal menunjukkan bahwa rata-rata secara kelasikal menunjukkan hasil yang cukup rendah sebesar 74,4 karena dibawah batas ketuntasan belajar minimal (KKM) yaitu 79. Dilihat secara individual, terdapat 12 peserta didik yang nilai ketuntasan belajarnya di bawah standar dari 31 peserta didik. Dari 31 peserta didik yang aktif bertanya di kelas selama proses pembelajaran berlangsung sebanyak 6 peserta didik. Sedangkan yang selalu menjawab pertanyaan saat guru sedang mengajukan pertanyaan ada sebanyak 5 peserta didik. Peserta didik yang diam saja pada saat pembelajaran berlangsung ada 2 peserta didik. Peserta didik yang sering mengganggu temannya pada saat di kelas dan di laboratorium ada sebanyak 4 peserta didik. Ada juga peserta didik yang mengantuk pada saat peneliti sedang mengajar di kelas yaitu sebanyak 4 peserta didik. 6 peserta didik sering berbicara dengan temannya. Hampir semua peserta didik dikelas sebanyak 31 peserta didik yang mendengarkan materi, 27 peserta didik memperhatikan pelajaran, sedang yang 4 tidak memperhatikan. Pada saat guru menyuruh peserta didik mencatat materi hanya 1 peserta didik saja yang tidak mau mencatat.

Hasil pre test kemampuan belajar ( Tes Praktek ) pada kondisi awal menunjukkan bahwa rata-rata secara kelasikal menunjukkan hasil yang cukup rendah sebesar 73,6karena dibawah 
batas ketuntasan belajar minimal (KKM) yaitu 79. Dilihat secara individual, terdapat 17peserta didik yang nilai ketuntasan belajarnya di bawah standar dari 31 peserta didik. Dari 31peserta didik yang aktif bertanya di kelas selama proses pembelajaran berlangsung sebanyak 6peserta didik. Sedangkan yang selalu menjawab pertanyaan saat guru sedang mengajukan pertanyaan ada sebanyak 5peserta didik.Peserta didik yang diam saja pada saat pembelajaran berlangsung ada 3 peserta didik. Peserta didik yang sering mengganggu temannya pada saat di kelas dan di laboratorium ada sebanyak 5peserta didik. Ada juga peserta didik yang mengantuk pada saat peneliti sedang mengajar di kelas yaitu sebanyak 4 peserta didik. 6 peserta didik sering berbicara dengan temannya. Hampir semua peserta didik dikelas sebanyak 31 peserta didik yang mendengarkan materi, 26peserta didikmemperhatikan pelajaran, sedang yang 5 tidak memperhatikan. Pada saat guru menyuruh peserta didik mencatat materi hanya 1 peserta didik saja yang tidak mau mencatat.

Hasil pre test pada kondisi awal menunjukkan bahwa rata-rata secara kelasikal menunjukkan hasil yang cukup rendah sebesar 74,4karena dibawah batas ketuntasan belajar minimal (KKM) yaitu 79. Sedangkan Hasil siklus I mengalami peningkatan menjadi 77,2 meskipun masih di bawah batas ketuntasan belajar minimal (KKM) yaitu 79. Siswa yang mengalami peningkatan dari pre test ke siklus 1 yaitu 13 siswa, yang tidak mengalami peningkatan 2 siswa, dan yang mengalami pengurangan 16 siswa.

Hasil pre test pada kondisi awal menunjukkan bahwa rata-rata secara kelasikal menunjukkan hasil yang cukup tinggisebesar 83,9 karena diatas batas ketuntasan belajar minimal (KKM) yaitu 79. Sedangkan Hasil siklus I mengalami peningkatan menjadi 89,2. Siswa yang mengalami peningkatan dari pre test ke siklus 1 yaitu 25 siswa, yang tidak mengalami peningkatan 1 siswa, dan yang mengalami pengurangan 5 siswa.

Berdasarkan hasil belajar pada siklus I tes tertulis diketahui bahwa tindakan yang dilakukan peneliti berupa penerapan model pembelajaran melalui media Proyektor LCD ternyata dapat meningkatkan hasil belajar TIKmateri Mcrosoft Excel peserta didikkelasVIII DSMP N 1 Teras dibandingkan hasil pre tes tes tertulis meskipun peningkatan tersebut sudah signifikan tetapi rata-rata secara kelasikal masih dibawah standar ketuntasan minimal (79). Apabila dilihat secara individu, peserta didik dengan nilai dibawah standard berkurang jumlahnya dari 12peserta didik menjadi 9peserta didik. Sedangkan hasil pre tes tes praktek peningkatan nilai sudah signifikan dengan nilai diatas standard semua dan siswa yang mengalami peningkatan 25 siswa. Berdasarkan hasil tersebut guru memberikan motivasi kepada peserta didik tentang pentingnya belajar melalui media Proyektor LCD ternyata dapat meningkatkan hasil belajar TIKmateri Mcrosoft Excel. Guru memberikan penguatan tentang proses kegiatan belajar yang telah dilaksanakan untuk mempersiapkan/melanjutkan proses pembelajaran berikutnya. Mengingat dalam siklus I menunjukkan adanya kemajuan, maka peneliti berpendapat untuk melanjutkan siklus II dengan kegiatan yang sama dengan berkelompok dengan 1 unit komputer 2 peserta didik.

Hasil tes tertulis pada kondisi siklus I menunjukkan bahwa rata-rata secara kelasikal menunjukkan hasil yang cukup rendah sebesar 77,2 karena dibawah batas ketuntasan belajar minimal (KKM) yaitu 79. Sedangkan Hasil siklus II mengalami peningkatan menjadi 89,5. Siswa yang mengalami peningkatan dari pre test ke siklus 1 yaitu 25 siswa, yang tidak mengalami peningkatan 24 siswa, yang tetap 2 siswa dan yang mengalami pengurangan 5 
siswa.

Hasil tes praktek pada siklua I menunjukkan bahwa rata-rata secara kelasikal menunjukkan hasil yang cukup tinggi sebesar 89,2 karena diatas batas ketuntasan belajar minimal (KKM) yaitu 79. Sedangkan Hasil siklus I mengalami peningkatan menjadi 93,3. Siswa yang mengalami peningkatan dari pre test ke siklus 1 yaitu 25 siswa, yang tidak mengalami peningkatan 22siswa, yang tetap 2 siswa dan yang mengalami pengurangan 7 siswa.

Berdasarkan hasil belajar pada siklus II diketahui bahwa tindakan yang dilakukan peneliti berupa penerapan model pembelajaran menggunakan media proyektor LCD ternyata dapat meningkatkan hasil belajar TIK Materi Microsoft Excel peserta didikkelasVIII D dibandingkan dengan siklus I dan peningkatan tersebut cukup signifikan karena rata-rata secara kelasikal sudah berada diatas standar ketuntasan minimal (79). Apabila dilihat secara individu, peserta didik dengan nilai dibawah standard berkurang jumlahnya dari 10peserta didik menjadi tuntas semua. Berdasarkan hasil tersebut, guru menanamkan motivasi kepada peserta didik tentang pentingnya model pembelajaran melaui media proyektor LCD dalam pembelajaran TIK. Dalam pemberian motivasi ini diberikan saran, pujian terutama terhadap peserta didik yang aktif dalam menjawab pertanyaan maupun bertanya kepada guru dan selanjutnya memberi penguatan tentang hasil-hasil pembelajaran yang telah dilaksanakan untuk mempersiapkan/melanjutkan proses pembelajaran berikutnya. Mengingat dalam siklus II menunjukkan adanya kemajuan, maka peneliti tidak perlu mengadakan penelitian ke siklus berikutnya.

Setelah melaksanakan dan menyelesaikan tindakan pada setiap siklus sebagaimana telah dideskripsikan di atas kemudian dilakukan pembahasan data. Adapun data-data yang diperoleh guru sebagai bahan analisis dan evaluasi tentang frekuensi nilai peserta didik sebagai berikut

Tabel 1. Hasil belajar Peserta didik Sebelum Tindakan Kelas ( tes praktek)

\begin{tabular}{ccc}
\hline NILAI & JUMLAH & PROSENTASE \\
\hline Kurang dari 50 & 0 & $0 \%$ \\
$50-59$ & 4 & $13 \%$ \\
$60-69$ & 4 & $13 \%$ \\
$70-79$ & 16 & $52 \%$ \\
$80-89$ & 6 & $19 \%$ \\
$90-100$ & 1 & $3 \%$ \\
Jumlah peserta didik & 31 & $100 \%$ \\
\hline Rata-rata & 74,4 &
\end{tabular}

Tabel 1, dapat dilihat kondisi/keadaan awal sebelum diberikan tindakan dalam hal ini berupa nilai hasil belajar TIK materi Microsoft Excel yang diperoleh dalam kegiatan belajar mengajar sebelum penerapan model pembelajaran menggunakan media proyektor LCD, nilai yang terdapat pada tabel dipergunakan sebagai tolok ukur untuk mengetahui hasil belajar peserta didik terhadap materi tentang Microsoft Excel.

Pada keadaan awal ini dapat kita lihat nilai rata-rata hasil belajar peserta didik74,4 dengan prosentase masing-masing angka seperti dalam tabel. Pada tahap ini peserta didik banyak yang mendapat nilai random yaitu $<70$ sebanyak $77 \%$, sedangkan yang memperoleh 70 ke atas sebanyak 23\%. Hal ini menunjukkan proses belajar mengajar yang dilaksanakan oleh 
guru belum mencapai hasil yang optimal.

Tabel 2. Hasil belajar Peserta didikSebelum Tindakan Kelas / Siklus I (tes tertulis)

\begin{tabular}{ccc}
\hline NILAI & JUMLAH & PROSENTASE \\
\hline Kurang dari 50 & 1 & $3 \%$ \\
$50-59$ & 3 & $10 \%$ \\
$60-69$ & 5 & $16 \%$ \\
$70-79$ & 8 & $26 \%$ \\
$80-89$ & 10 & $32 \%$ \\
$90-100$ & 4 & $13 \%$ \\
Jumlah peserta didik & 31 & $100 \%$ \\
\hline Rata-rata & 73,6 &
\end{tabular}

Setelah mengadakan tindakan kelas sebelum tindakan kelasini untuk materi pelajaran tes tertulis, dapat kita lihat nilai rata-rata hasil belajar peserta didik73,6 dengan prosentase masingmasing angka seperti dalam tabel. Pada tahap ini peserta didik banyak yang mendapat nilai random yaitu $<70$ sebanyak $55 \%$, sedangkan yang memperoleh 70 ke atas sebanyak $45 \%$. Hal ini menunjukkan proses belajar mengajar yang dilaksanakan oleh guru sudah mencapai hasil yang baik akan tetapi belum optimal. Oleh karena itu penulis akan mengadakan tindakan untuk siklus berikutnya yaitu mengadakan tindakan kelas siklus II.

Sebelum penulis mengadakan tindakan siklus II, di bawah ini akan ditampilkan Nilai Hasil Peserta didik untuk materi Microsoft Excel praktek. Karena melihat hasil dari nilai peserta didik belum optimal maka peneliti mengadakan tindakan berikutnya yaitu siklus I untuk tes praktek materi Microsoft Excel menggunakan proyektor LCD. Adapun hasil belajarnya seperti pada tabel 3 .

Tabel 3. Hasil belajar Peserta didik Setelah Tindakan Kelas / Siklus I (tes praktek )

\begin{tabular}{ccc}
\hline NILAI & JUMLAH & PROSENTASE \\
\hline Kurang dari 50 & 0 & $0 \%$ \\
$50-59$ & 0 & $0 \%$ \\
$60-69$ & 0 & $0 \%$ \\
$70-79$ & 0 & $0 \%$ \\
$80-89$ & 18 & $58 \%$ \\
$90-100$ & 13 & $42 \%$ \\
Jumlah peserta didik & 31 & $100 \%$ \\
\hline Rata-rata & 89,2 &
\end{tabular}

Peneliti setelah mengadakan tindakan kelas pada siklus I tes praktek untuk materi pelajaran Microsoft Excel dan sudah menggunakan proyektor LCD, dapat kita lihat nilai ratarata hasil belajar peserta didik 89,2 dengan prosentase masing-masing angka seperti dalam tabel. Pada tahap ini peserta didik yang mendapat nilai random yaitu $<70$ sebanyak $0 \%$, nilai antara 80-89 sebanyak 58\% sedangkan yang memperoleh 90 ke atas sebanyak 42\%. Hal ini menunjukkan proses belajar mengajar yang dilaksanakan oleh guru sudah mencapai hasil yang maksimal akan tetapi peneliti akan mengadakan siklus II untuk penelitian berikutnya. 
Tabel 4. Hasil belajar Peserta didik Setelah Tindakan Kelas / Siklus I (tes tertulis)

\begin{tabular}{ccc}
\hline NILAI & JUMLAH & PROSENTASE \\
\hline Kurang dari 50 & 3 & $10 \%$ \\
$50-59$ & 0 & $0 \%$ \\
$60-69$ & 5 & $16 \%$ \\
$70-79$ & 2 & $6 \%$ \\
$80-89$ & 10 & $32 \%$ \\
$90-100$ & 11 & $35 \%$ \\
Jumlah peserta didik & 31 & $100 \%$ \\
\hline Rata-rata & 77,2 &
\end{tabular}

Setelah mengadakan tindakan kelas sebelum tindakan kelasini untuk materi pelajaran tes tertulis, dapat kita lihat nilai rata-rata hasil belajar peserta didik 77,2 dengan prosentase masing-masing angka seperti dalam tabel. Pada tahap ini peserta didik banyak yang mendapat nilai random yaitu $<70$ sebanyak $32 \%$, sedangkan yang memperoleh 70 ke atas sebanyak $68 \%$. Hal ini menunjukkan proses belajar mengajar yang dilaksanakan oleh guru sudah mencapai hasil yang baik akan tetapi belum optimal. Oleh karena itu penulis akan mengadakan tindakan untuk siklus berikutnya yaitu mengadakan tindakan kelas siklus II.

Sebelum penulis mengadakan tindakan siklus II, di bawah ini akan ditampilkan Nilai Hasil Peserta didik untuk materi Microsoft Excel praktek.

Tabel 4. Hasil belajar Peserta didik Setelah Tindakan Kelas / Siklus II (tes tertulis)

\section{NILAI}

Kurang dari 50

$50-59$

$60-69$

$70-79$

$80-89$

$90-100$

Jumlah peserta didik

Rata-rata

\section{JUMLAH}

0

0

0

3

9

19

31
PROSENTASE

$0 \%$

$0 \%$

$0 \%$

$10 \%$

$29 \%$

$61 \%$

$100 \%$

Pada tahap ini peserta didik yang mendapat nilai random yaitu $<70$ sebanyak $10 \%$, nilai antara 80-89 sebanyak 29\% sedangkan yang memperoleh 89 ke atas sebanyak $61 \%$. Hal ini menunjukkan proses belajar mengajar yang dilaksanakan oleh guru sudah mencapai hasil yang baik dan meningkat akan tetapi peneliti akan mengadakan ke siklus II dengan tes praktek.

Tabel 5. Hasil belajar Peserta didik Setelah Tindakan Kelas / Siklus II (tes praktek )

\begin{tabular}{ccc}
\hline NILAI & JUMLAH & PROSENTASE \\
\hline Kurang dari 50 & 0 & $0 \%$ \\
$50-59$ & 0 & $0 \%$ \\
$60-69$ & 0 & $0 \%$ \\
$70-79$ & 0 & $0 \%$ \\
$80-89$ & 6 & $19 \%$
\end{tabular}




\begin{tabular}{ccc}
$90-100$ & 25 & $81 \%$ \\
Jumlah peserta didik & 31 & $100 \%$ \\
\hline Rata-rata & 93,3
\end{tabular}

Pada siklus II dalam tes praktek ini peserta didik yang mendapat nilai yang cukup meningkat dan sangat memuaskan yaitu yang mendapatkan nilairandom yaitu80-89 sebanyak 19\%,sedangkan yang memperoleh 90-100 sebanyak 81\%. Hal ini menunjukkan proses belajar mengajar yang dilaksanakan oleh guru sudah mencapai hasil yang sangat baik dan meningkat. Dibawah ini akan peneliti tampilkan perbandingan antara Siklus I dan Siklus II setelah peserta didik mengikuti proses belajar mengajar menggunakan Proyektor LCD.

Tabel 6. Nilai Peserta didik Setiap Siklus Setelah Mengikuti Proses Belajar Mengajar dengan Penerapan Menggunakan Proyektor LCD (tes praktek)

\begin{tabular}{ccccc}
\hline \multirow{2}{*}{ NILAI } & \multicolumn{2}{c}{ SIKLUS I } & \multicolumn{2}{c}{ SIKLUS II } \\
\cline { 2 - 5 } & JUMLAH & $\%$ & JUMLAH & $\%$ \\
\hline Kurang dari 50 & 0 & $0 \%$ & 0 & $0 \%$ \\
$50-59$ & 0 & $0 \%$ & 0 & $0 \%$ \\
$60-69$ & 0 & $0 \%$ & 0 & $0 \%$ \\
$70-79$ & 0 & $0 \%$ & 0 & $0 \%$ \\
$80-89$ & 18 & $58 \%$ & 6 & $19 \%$ \\
$90-100$ & 13 & $42 \%$ & 25 & $81 \%$ \\
JUMLAH & 31 & $100 \%$ & 31 & $100 \%$ \\
\hline RATA-RATA & & 89,2 & &
\end{tabular}

Pada tabel 6 dapat dilihat hasil tindakan dari tiap siklus. Pada siklus I jumlah anak yang mendapat nilai 80-89 sebanyak 18 anak sedangkan yang mendapat nilai 90-100 sebanyak 13 anak. Dengan demikian sekitar 58\% anak yang mencapai hasil nilai yang sudah baik, sedangkan yang mendapat hasil belajar yang memuaskan baru 42\%. Rata-rata kelas 89,2 jika dibandingkan dengan hasil belajar awal, pada siklus I ini telah menunjukkan peningkatan.

Pada siklus II nilai rata-rata kelas 93,3 dapat kita lihat adanya peningkatan nilai hasil belajar peserta didik bila dibandingkan dengan nilai hasil belajar peserta didik pada siklus I. Peningkatan yang ditunjukkan cukup signifikan. Jumlah anak yang mendapat nilai 80-89 sebanyak 6 anak atau 19\% dari jumlah seluruh peserta didik, sedangkan anak yang mendapat nilai 90-100 sebanyak 25 anak atau 81\% dari jumlah seluruh peserta didik. Dengan demikian hasil belajar peserta didik mengalami peningkatan dalam proses belajar mengajar siklus II setelah guru menerapkan model pembelajaran menggunakan proyektor LCD.

Hal ini menunjukkan bahwa penerapan model pembelajaran menggunakan proyektor LCD dalam proses belajar mengajar berpengaruh terhadap hasil belajar yang dicapai oleh peserta didik. Sehubungan dengan itu maka dapat disimpulkan bahwa tindakan guru melalui penerapan model pembelajaran menggunakan proyektor LCD dalam pembelajaran Microsoft Excel pada peserta didik kelas VIII DSMP N 1 Terastelah berhasil meningkatkan hasil belajar peserta didik yang ditunjukkan dengan peningkatan nilai peserta didik setiap siklus. Melalui penggunaan model pembelajaran menggunakan proyektor LCD, peserta didik lebih mudah dalam memahami penjelasan guru, seperti yang terlihat dari hasil penyebaran angket pada 
tabel 7.

Tabel 7. Data Hasil Observasi Dalam Kaitannya dengan Penggunaan Media Proyektor LCD

\begin{tabular}{llc}
\hline \multicolumn{1}{c}{ Angket Penggunaan Media ProyektorLCD } & Tanggapan Peserta didik \\
\hline 1. $\begin{array}{l}\text { Belajar dengan menggunakan model pembelajaran } \\
\text { menggunakan proyektor LCD lebih menyenangkan. }\end{array}$ & $90 \%$ setuju \\
2. Mempelajari materi Microsoft Excel lebih mudah & $98 \%$ setuju \\
dipahami dan lebih jelas & $95 \%$ setuju \\
3. Guru yang menggunakan model pembelajaran & \\
menggunakan proyektor LCDmenyenangkan & $98 \%$ setuju \\
peserta didik dan tidak membosankan. & \\
Guru menjelaskan materi Microsoft Excel dengan \\
$\begin{array}{l}\text { peserta didik. } \\
\text { Peserta didik lebih mudah dalam mempraktekkan }\end{array}$
\end{tabular}

\section{PENUTUP}

Kemampuan dan perolehan nilai peserta didikdi SMP N 1 Teras Boyolali dalam pembelajaran TIK ( Tehnologi Informasi dan Komunikasi ) materi Microsoft Excel peserta didik kelas VIII D Semester II Tahun Pelajaran 2015/2016, selalu mengalami peningkatan dari satu siklus ke siklus berikutnya. Hal itu mengindikasikan adanya peningkatan kemampuan dan hasil belajar peserta didik terhadap materi Microsoft Excel.

Sesuai keseluruhan siklus yang telah dilakukan, dapat disimpulkan bahwa penerapan model pembelajaran menggunakan media proyektor LCD ternyata dapat meningkatkan kemampuan dan hasil belajar peserta didik terhadap materi Microsoft Excel di klas VIII D. Dalam setiap siklus selalu membawa dampak yang positif kearah peningkatan kemampuan dan hasil belajar peserta didik. Selain itu dengan penerapan mepenggunaan proyektor LCD membuat suasana kelas menjadi kondusif, peserta didik menjadi tertarik, aktif, kreatif, efektif dan menyenangkan (PAKEM) serta tidak ada kejenuhan.

\section{DAFTAR PUSTAKA}

Amien, M. 1987. Pendidikan Science. Yogyakarta: FKIE IKIP.

Darmawan Deni, 2012, Teknologi Pembelajaran, Bandung, PT. Remaja Rosdakarya

Departemen Pendidikan Dan Kebudayaan. 1990. Kamus Besar Bahasa Indonesia. Jakarta: Balai Pustaka . 1986. Dasar-dasar Kependidikan. Jakarta : Dirjen Dikdasmen. . 2005. Kamus Besar Bahasa Indonesia.Jakarta : Balai Pustaka

Dimyati dan Mujiono. 2002. Belajar dan Pembelajaran. Jakarta: Rineka Cipta

Hamzah, H. 2010. Teknologi Komunikasi dan Informasi Pembelajaran. Jakarta, Bumi Aksara.

Pandia Henry, 2009. Teknologi Informasi dan Komunikasi untuk SMP Kelas VIII. Jakarta, Erlangga 
Purwanto, 2011. Evaluasi Hasil Belajar, Yogyakarta, Pustaka Pelajar

Putra Rahmat, 2009. Microsoft Excel. Jakarta, Erlangga.

Rusman, 2012, Belajar dan Pembelajaran Berbasis Komputer, Mengembangkan Profesionalisme Guru Abad 21, Bandung, Alfabeta

Rusman, Deni Kurniawan, Cepi Riyana, 2011, Pembelajaran Berbasis Teknologi Informasi dan Komunikasi, Mengembangkan Profesionalitas Guru, Jakarta, PT. Raja Grafindo Persada

Soekartawi, 1985, Meningkatkan Efektivitas Mengjar, Jakarta : Pustaka Jaya.

Subroto, Suryo, (1996), Proses Belajar Mengajar di Sekolah, Jakarta :Rineka Cipta.

Supriyanto, 2007.Teknologi Informasi dan Komunikasi 2 Kelas VIII, $\quad$ P e n e r b i t :Yudhistira.

Usman, MU (1996), Menjadi Guru Profesional, Bandung : Remaja Rosda Karya.

Winarno, Abdullah, Abu Yasid, Rini Marzuki, 2009, Teknik Evaluasi Multimedia Pembelajaran, Jakarta, Genius Prima Media 